\title{
NEW DATA ON THE CHRONOLOGY AND DEVELOPMENT OF CATTLE BREADING DURING THE ENEOLITHIC AND EARLY BRONZE AGE IN THE SOUTHERN URAL REGION ${ }^{1}$
}

\author{
Nina L. Morgunova \\ Orenburg State Pedagogical University, Orenburg, Russian Federation \\ Natalia V. Roslyakova \\ Samara State University of Social Sciences and Education, Samara, Russian Federation \\ Marianna A. Kulkova \\ Herzen State Pedagogical University, Saint Petersburg, Russian Federation
}

\begin{abstract}
Introduction. The article considers the features of cattle breeding and consumption of meat products in the Eneolithic cultures (the Samara culture) and the Early Bronze Age cultures (the Repin stage of the Pit Grave culture) on the territory of the Southern Urals (the Samara Trans-Volga region). The paper specifies the chronology of these cultures on the base of radiocarbon dating. The main site for the study was Turganik settlement located in the Southern Ural region (Orenburg region). Methods. More than $800 \mathrm{~m} 2$ of the settlement area was excavated. There were six paleosoil layers. Four upper layers were empty, without artifacts. The sixth layer contained Eneolithic finds. The fifth layer contained finds of the Early Bronze Age. The archaeozoological collection was analyzed in accordance with the methodological scheme developed by E.E. Antipina. For radiocarbon dating collagen was treated from bone samples on the base of the standard procedure and radiocarbon activity was measured by Quantulus 1220 low background scintillation counter. Analysis and Results. As a result 32 radiocarbon dates were obtained on animal bones and on organics from pottery of different types from different cultural layers of Turganik settlement. The Eneolithic complex includes ceramics, flint and bone tools. The paper specifies the finds of developed and later stages of the Samara culture. The artifacts of the second stage of the Samara culture were dated to $4900-4500$ cal BC. The artifacts of the later stage belong to the period of $4300-3800 \mathrm{cal}$ BC. We suggest that from the Early Eneolithic local people practiced cattle breeding without agriculture. Hunting played a secondary role and fishing was poorly developed. Beef was the main food in the people's diet during the Eneolithic period. The Early Bronze Age assemblage includes ceramics of the Repin stage of the Pit Grave culture, stone macro-tools, flint arrowheads, items made of bones and copper, slags and scarps of copper ore. The technological analysis supported that ceramics belong to the Pit Grave culture. The layer age is from 3800 to 3300 cal BC. During the Repin stage the role of sheep breeding was increased and consumption of sheep meat prevailed in comparison with the Eneolithic period. This is an evidence of the transition to the nomadic form of stock breeding.

Key words: Southern Ural region, Eneolithic period, Samarian culture, Early Bronze Age, Pit Grave culture, cattle breading.

Citation. Morgunova N.L., Roslyakova N.V., Kulkova M.A. New Data on the Chronology and Development of Cattle Breading During the Eneolithic and Early Bronze Age in the Southern Ural Region. Vestnik Volgogradskogo gosudarstvennogo universiteta. Seriya 4. Istoriya. Regionovedenie. Mezhdunarodnye otnosheniya [Science Journal 5 of Volgograd State University. History. Area Studies. International Relations], 2019, vol. 24, no. 3, pp. 17-36. (in Russian). DOI: https://doi.org/10.15688/jvolsu4.2019.3.2
\end{abstract}




\title{
НОВЫЕ ДАННЫЕ О ХРОНОЛОГИИ И РАЗВИТИИ СКОТОВОДСТВА В ЭНЕОЛИТЕ И РАННЕМ БРОНЗОВОМ ВЕКЕ ЮЖНОГО ПРИУРАЛЬЯ 1
}

\author{
Нина Леонидовна Моргунова
}

Оренбургский государственный педагогический университет, г. Оренбург, Российская Федерация

\section{Наталья Валерьевна Рослякова}

Самарский государственный социально-педагогический университет, г. Самара, Российская Федерация

\section{Марианна Алексеевна Кулькова}

Российский государственный педагогический университет им. А.И. Герцена, г. Санкт-Петербург, Российская Федерация

Аннотация. В статье поставлена задача рассмотреть особенности развития скотоводства и потребления населением мясных продуктов в культурах эпохи энеолита (самарская культура) и ранней бронзы (репинский этап ямной культуры) на территории Южного Приуралья (Самарского Заволжья) и угочнить хронологию этих культур с использованием данных радиоуглеродного датирования. Опорным памятником для исследования явилось Турганикское поселение в Южном Приуралье (Оренбургская область). Исследовано около 800 м² площади поселения. Выделено 6 слоев палеопочвенных отложений, из которых 4 верхних слоя представляли собой слои балласта без артефактов. Слой 6 характеризовался преимущественным содержанием материалов энеолита, слой 5 - раннего бронзового века. Археозоологический материал обрабатывался и анализировался по методической схеме, разработанной Е.Е. Антипиной. Пробоподготовка образцов и датирование костной ткани проводились по стандартной методике по коллагену. Активность радиоуглерода измерялась с использованием низкофонового сцинтилляционного счетчика Quantulus 1220. Получено 32 радиоуглеродных даты по костям животных и по керамике разных типов из соответствующих культурных слоев поселения. Комплекс энеолита включает керамику, кремневые и костяные изделия. Выделены материалы развитого и позднего этапов самарской культуры. Материалы II этапа самарской культуры датированы 4900-4500 cal BC, материалы позднего этапа датированы в рамках 4300-3800 cal BC. Сделан вывод о преимущественном развитии, начиная с энеолита, скотоводства у местного населения при отсутствии земледелия. Охота играла подсобную роль, рыболовство было развито слабо. В энеолите в питании жителей поселения преобладала говядина. Комплекс раннего бронзового века представлен керамикой репинского этапа ямной культуры, каменными макроорудиями, кремневыми наконечниками стрел, изделиями из кости и меди, шлаками и фрагментами медной руды. Принадлежность керамики ямной культуре подтверждается технологическим анализом керамики. Слой датирован в пределах 3800-3300 cal BC. В сравнении с энеолитом на репинском этапе возросла роль овцеводства и потребление мяса овец, что свидетельствует о перерастании скотоводства в кочевую форму. Представленный материал является результатом совместной работы авторов: под руководством Н.Л. Моргуновой проведены раскопки Турганикского поселения, разработана общая концепция работы, обобщены литературные данные и подготовлен основной текст рукописи; М.А. Кульковой проведен радиоуглеродный анализ большинства образцов и обобщены полученные данные, Н.В. Росляковой выполнен археозоологический анализ и обобщены результаты.

Ключевые слова: Южный Урал, эпоха энеолита, самарская культура, ранний бронзовый век, ямная культура, скотоводство.

Цитирование. Моргунова Н. Л., Рослякова Н. В., Кулькова М. А. Новые данные о хронологии и развитии скотоводства в энеолите и раннем бронзовом веке Южного Приуралья // Вестник Волгоградского государственного университета. Серия 4, История. Регионоведение. Международные отношения. - 2019. - Т. 24, № 3. - C. 17-36. - DOI: https://doi.org/10.15688/jvolsu4.2019.3.2

Введение. В задачу настоящей работы входит рассмотрение особенностей развития скотоводства и потребления населением мясных продуктов в культурах эпохи энеолита и ранней бронзы на территории Южного Приуралья (Самарского Заволжья) и уточнение хронологии этих культур с использованием данных радиоуглеродного датирования. На погра- 
ничье степи и лесостепи меридионально располагается достаточно разветвленный бассейн р. Самара. Одним из крупных притоков p. Самара является р. Ток, где исследовано Турганикское поселение [18; 31]. Большую научную значимость материалы поселения приобрели в связи с проблемой абсолютной хронологии самарской и раннего этапа ямной культур, определения их преемственности и взаимосвязи, в том числе в связи с хозяйственной деятельностью.

Самарская культура была выделена по материалам грунтового могильника у с. Съезжее $[4 ; 5]$. Позднее по материалам Ивановского поселения в развитии культуры было намечено наличие 2 этапов [18-20]. В настоящее время обоснована 3-этапная периодизация самарской культуры $[21 ; 31]$. Ямная культура Волго-Уралья имеет более длительную историю исследований [15; 23, с. 14-35].

В рассмотрении поставленной темы возникают два взаимосвязанных и дискуссионных блока проблем.

Первый блок связан с обоснованием хронологии самарской и ямной культур и определением степени преемственности между ними. Абсолютная хронология самарской культуры, особенно на 2-м этапе развития, была достаточно надежно обоснована по линии синхронизации с хвалынской культурой и серией ${ }^{14} \mathrm{C}$ дат, полученных в основном по керамике [21, с. 122 133]. Как будет показано далее, значения ${ }^{14} \mathrm{C}$ дат по костям животных из энеолитического слоя Турганикского поселения полностью подтвердили прежние результаты.

Однако абсолютные датировки самарской и хвалынской культур вывели на новый виток дискуссии проблему происхождения ямной культуры, поскольку образовался значительный разрыв между калиброванными интервалами тех и других. На этом основании была поставлена под сомнение модель, предложенная И.Б. Васильевым [4] и поддержанная Н.Я. Мерпертом [16], о сложении ямной культуры в Волго-Уральском междуречье на базе хвалынской и самарской культур [2; 32]. При этом в определении хронологии ямной культуры опирались в основном на данные по памятникам развитого этапа, а даты для памятников репинского этапа практически не были известны [36].
В то же время появились первые ${ }^{14} \mathrm{C}$ данные, значительно удревняющие репинский этап ямной культуры. Так, по фрагментам керамики Турганикского поселения и стоянок КызылХак I и II в Северном Прикаспии были получены радиоуглеродные даты, указывающие на их синхронность майкопской культуре [33]. Аналогичные значения дат, но опять же по керамическому материалу, были сделаны для ряда репинских погребальных комплексов [22]. Но полученные даты противоречили существующим представлениям о хронологии раннего (репинского) этапа ямной культуры и вызвали недоверие, прежде всего в связи с отбором керамики для датирования [3; 11]. Однако другие материалы для данной цели в то время не были доступны. Именно поэтому и было выбрано Турганикское поселение для продолжения раскопок и отбора качественных материалов для радиоуглеродного датирования.

Второй блок проблем данной темы касается динамики становления и степени развития скотоводства у населения самарской культуры и на раннем этапе ямной культуры.

Что касается ямной культуры, то скотоводческий характер ее хозяйства был установлен еще в 60-е гг. прошлого века [15; 37]. Это удалось сделать в основном благодаря открытиям таких выдающихся памятников, как поселения Хутор Репин и Михайловское (слой 2) на Днепре [12; 30; 35]. При этом Н.Я. Мерперту удалось показать не только производящий характер экономики ямного населения степной Восточной Европы, но и ее специфику, заключающуюся в господстве скотоводческого направления, причем в подвижной, кочевой форме [15]. Однако оставался невыясненным вопрос об истоках столь развитого уровня скотоводства, поскольку данные по предшествующему этапу энеолита на территории Волжско-Уральского междуречья не были известны.

Первые материалы о становлении производящего хозяйства в степной-лесостепной зоне Волжско-Уральского региона стали появляться лишь с середины 70-х гг. ХХ века. На материалах энеолитических могильников Съезжее и Хвалынский I И.Б. Васильев показал ведущую роль скотоводства, наряду с охотой и рыболовством, в хозяйстве населения самарской и хвалынской культур [4, с. 66-71]. 
Подтверждение данный вывод получил на материалах поселений эпохи энеолита и даже неолита $[14 ; 20]$. Результаты исследований достаточно подробно опубликованы [29]. Они отчасти использовались в специальных работах [24; 39]. Однако дискуссия относительно наличия скотоводства в самарской культуре, не говоря уже о неолите, ввиду многослойности таких памятников, как Ивановка и Муллино, сохраняется [23, с. 256-292].

Что касается ямной культуры ВолгоУралья, то в свое время Н.Я. Мерперт, доказывая вывод о ее скотоводческом характере, основывался на небольшом числе костных останков в погребениях. Поселения типа Хутор Репин в Заволжье были не известны. Согласно методике археозоологии, находки костей животных в погребениях дают представление о значении разных видов животных в ритуальной практике древнего населения, но не могут рассматриваться в качестве основного источника для реконструкции мясной диеты населения и тем более его хозяйства.

Материалы. В связи с вышесказанным чрезвычайно важными нам представляются новые материалы, которые были получены в результате раскопок, проведенных на Турганикском поселении, расположенном в северной части Волго-Уральского междуречья.

Материалы эпох энеолита и раннего бронзового века содержатся в конкретных культурных слоях, что позволяет проследить динамику эволюции хозяйственной деятельности местного населения на протяжении длительного времени. Важно и то, что получено достаточное количество радиоуглеродных дат по костям животных, не дающих резервуарного эффекта, позволяющих уточнить хронологию данных этапов.

Анализ. Поселение находится в северозападной части Оренбургской области (рис. 1). Оно располагается в месте впадения р. Турганик в старое русло р. Ток. Первые раскопки были произведены в начале 80-х гг. ХХ в. [18]. Было выявлено 2 культурных слоя - самарской культуры эпохи энеолита (далее - ЭЭ) и раннего бронзового века (далее - РБВ). В 450 м к Ю3 в те же годы исследовалось многослойное Ивановское поселение. В среднем слое этого поселения находились мате- риалы, аналогичные находкам из слоя ЭЭ Турганикского поселения [19].

В 2014 г. раскопки Турганикского поселения были возобновлены. Исследовано око-

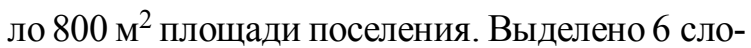
ев палеопочвенных отложений, из которых 4 верхних слоя представляли собой слои балласта без артефактов. Слои 5 и 6 являлись культурными. Слой 6 характеризовался преимущественным содержанием материалов ЭЭ, слой 5 - РБВ. Зафиксированы планиграфические отличия размещения материалов ЭЭ и РБВ. Кроме представленных многочисленными артефактами комплексов ЭЭ и РБВ в 5-м и 4-м слоях поселения обнаружено небольшое число артефактов позднего бронзового века (далее - ПБВ). Ввиду невозможности связать с этими находками археозоологические материалы в данной статье они не рассматриваются.

В отличие от прошлых лет исследования проведены с привлечением к работе методов естественных наук, в том числе археозоологии (Н.В. Рослякова) и радиоуглеродного датирования (М.А. Кулькова).

Археозоологический материал обрабатывался и анализировался по методической схеме, разработанной Е.Е. Антипиной. Пробоподготовка образцов и датирование костной ткани проводилось по стандартной методике по коллагену. Активность радиоуглерода измерялась с использованием низкофонового сцинтилляционного счетчика Quantulus 1220.

Результаты исследований, включая материалы первых раскопок, опубликованы в виде коллективной монографии [31].

Комплекс эпохи энеолита. Комплекс ЭЭ включает керамику, кремневые и костяные изделия.

Выделяются два типа посуды: ивановского и токского типа, характерные для II этапа самарской культуры $[20 ; 21])$. Прослежен ряд архаичных съезжинских признаков на некоторых сосудах ивановского типа Турганикского поселения в сравнении с подобной керамикой Ивановского поселения.

Керамика ивановского типа отличается венчиками в виде «воротничка» (рис. 2, 1-3). Сосуды орнаментировались разнообразными узорами с помощью гребенчатых и веревочных штампов, насечками по срезу венчика. 
Для нанесения орнаментов использовались также плетеные материалы. Технологический анализ по всем показателям показал сочетание двух гончарных традиций в керамике ивановского типа: местной (поздненеолитической) и южной, связанной с гончарством орловской и хвалынской культур [31, с. 45-52]. Найдены фрагменты хвалынско-ивановского облика (рис. 2, 4-5). Технологический анализ этой керамики показал как ее сходство с керамикой Хвалынских могильников, так и отличия. При этом выявлены факты смешения традиций гончарства ивановского и хвалынского типов (использование идентичных схем орнаментальных композиций, а также плетеных фактур в технике орнаментирования).

Керамика токского типа представлена тонкостенными, крупными сосудами со слабопрофилированной или прямой горловиной (рис. 2, 6). Установлено, что сосуды по технологическим данным близки ивановскому типу. Орнаментальные композиции отличаются разреженностью узоров, они наносились в основном гребенчатыми штампами с широкими зубцами. Помимо основных типов керамики самарской культуры найдены единичные сосуды новоильинского (рис. 2, 7) и суртандинского (рис. 2, 8-9) типов.

Многочисленны изделия из кремня (около 2000 экз.). Основная их часть сконцентрирована в нижнем культурном слое вместе с керамикой ЭЭ, что подтверждается и планиграфически. Кремень хорошего качества, серых тонов. Большая часть находок кремня представлена сколами и отщепами без подработки. Пластины и изделия из них составляют около 60 \%. К ЭЭ отнесены многие поделки из рога и кости (наконечники, острия, лощила, пешни и др.), а также две находки медных предметов балканского происхождения [6, c. 24-25].

Выборка костей из 6-го слоя ЭЭ составляет 2282 фрагмента, из которых 1086 определены до вида (47,6 \%). Выборка состоит из костей млекопитающих $(98,7$ \%), птиц, рыб и рептилий. Кости млекопитающих принадлежат домашним (83,2 \%) и диким $(16,8 \%)$ видам животных (рис. 3). Домашние виды представлены костями крупного рогатого скота (далее - КРС) (Bos taurus), лошади (Equus caballus), мелкого рогатого скота (далее -
MPC) (Ovis/Capra) и собаки (Canis familiaris). В коллекции из Турганикского поселения определены кости овцы (Ovis aries) и козы (Capra hircus).

В остеологическом спектре домашних копытных доминируют кости МРС $(49,4 \%)$ и КРС (42,0 \%). Кости лошади составляют 8,6 \% (рис. 4). Разрозненные кости собак единичны. Не исключено, что кости лошади могут происходить от дикой лошади, на которую могло охотиться древнее население. Однако тот факт, что жители поселения на протяжении всего его существования разводили крупный рогатый скот и мелкий рогатый скот, позволяет предполагать, что они могли содержать в домашнем хозяйстве и лошадь.

Среди охотничьих видов в коллекции присутствуют: тур (Bos primigenius), лось (Alces alces), сайга (Saiga tatarica), кабан (Sus crofa ferus), медведь (Ursus arctos), волк (Canis lupus), лисица (Vulpes vulpes), барсук (Meles meles), бобр (Castor fiber) и сурок (Marmota $s p$.$) . Из 182$ костей 135 принадлежат бобру.

Подавляющее число костей животных является кухонными остатками, о чем свидетельствуют многочисленные следы искусственного воздействия на костях, которые были оставлены в процессе разделки туши и ее утилизации: порезы острым лезвием, надрубы, разрубы, следы разбивания костей, погрызы собаками. Также часто встречаются обгоревшие и кальцинированные кости.

Для оценки доли разных видов домашних копытных в мясном рационе населения в ЭЭ количество костей животных переведено в соотношение объемов мясных продуктов. Для этого количество костей каждого вида было умножено на коэффициент, равный кратности веса разных видов животных по отношению к одной туше овцы. Коэффициент подбирался с учетом возрастного состава животных и их размеров. В результате получилось, что основу мясного рациона жителей поселения составляла говядина. Реже употребляли в пищу мясо овец и коз. Доля конины в питании была незначительной.

Таким образом, анализ достаточно массовых материалов из слоя ЭЭ впервые позволил отчетливо зафиксировать преобладающую роль скотоводства в хозяйстве населения самарской культуры. 
Комплекс раннего бронзового века. Комплекс РБВ представлен керамикой, каменными макроорудиями, кремневыми наконечниками стрел, изделиями из кости и меди, шлаками и фрагментами медной руды. К РБВ относится котлован жилища, несколько ям и скоплений костей животных (рис. 5).

Керамический комплекс эпохи ранней бронзы Турганикского поселения состоит из около 2000 фрагментов от примерно 71 сосуда. Из них по способам обработки поверхности было выделено две группы керамики. Сосуды I группы с расчесами - поверхность заглажена гребенчатым, преимущественно крупным, реже мелким, штампом (55 сосудов). Сосуды II группы срубной культуры единичны.

В I группе выделены две категории сосудов: горшковидные и баночные. Первые подразделяются на профилированные и слабопрофилированные сосуды. Орнаментация разрежена, расположена в верхней части сосудов. Орнамент наносился с помощью гребенчатых штампов, палочкой, гладких длинных штампов, «веревочных» штампов и других приемов. Среди керамики с расчесами содержится значительное количество неорнаментированной керамики.

В результате технологического анализа установлено, что в качестве исходного сырья отбирались природные глины и илистые глины, в качестве примеси в основном использовалась дробленая раковина. Наличие двух устойчивых традиций при отборе исходного сырья свидетельствует о разных культурных группах, которые сложились еще в более раннее время и сохраняли данные навыки на период существования поселения.

Керамика с расчесами относится к репинскому этапу ямной культуры. Этот вывод, прежде всего, подтверждается данными технологического анализа керамики [28]. Кроме того, она находит аналогии в репинских материалах Шиловского поселения [27], а также в материалах поселения Михайловка на Днепре [9]. Сравнительный анализ типологии и, частично, технологии изготовления орнаментированной керамики с расчесами Турганикского поселения и керамики репинского типа Северного Прикаспия (Кзыл-Хак I и II) и Подонья (Хутор Репин, Копанище, Верхний Карабут-2, Черкасская) показал их значительную близость.
Особый интерес среди посуды с расчесами вызывают сосуды вида хумов [29]. Это крупные толстостенные сосуды с сильно отогнутыми и утолщенными венчиками (рис. 3, 7-8). По технологии хумы соответствуют керамике I группы. Подобный «хум» найден в погребении ямной культуры Переволоцкого могильника [25].

С репинским периодом существования поселения связана находка костяной булавкиамулета с рожками (рис. 5,10 ), аналогии которой известны в ранних ямных памятниках [7; 17; 23, c. 107, 134].

В слое РБВ получена весьма представительная серия, включающая 7157 костей животных, из них 3280 определимых.

В РБВ в остеологическом спектре на 19,3 \% вырастает доля МРС и на $16,2 \%$ уменьшается доля КРС. Такое соотношение домашних копытных, а также соотношение домашних и диких видов (соответственно 89,3 \% и $10,7 \%$ ) существенно отличается от таковых в ПБВ, когда количество диких животных на памятниках степной зоны Восточной Европы не превышает 2-3 \%, а среди домашних копытных по количеству костей всегда лидирует КРС (рис. 4). Доля костей КРС на памятниках ПБВ лесостепного Поволжья и Приуралья, как правило, составляет около 55-65 \%, МРС - 20$30 \%$, лошади $-12-15 \%$, свиньи $-2-4 \%$. Это сравнение дает основание считать, что выборка костей животных из слоя РБВ Турганикского поселения является достоверной и достаточной в количественном отношении для реконструкции мясной диеты населения.

Таким образом, в слоях как ЭЭ, так и РБВ существенно преобладают остатки домашних видов. Количество костей диких животных в выборке ЭЭ ненамного выше (на 6,3 \%), чем в выборке БВ (рис. 3). Этот вывод можно считать также достоверным, так как количество диких видов в целом увеличивается от верхних слоев поселения к нижним и на отдельных участках с увеличением на них керамики ЭЭ. Можно также отметить, что как в ЭЭ, так и в РБВ жители поселения охотились на крупных копытных (тура, лося, возможно лошадь), на сайгу, на хищных (медведя, волка, лисицу). И особенно активной была охота на бобра, чьи остатки составляют 69,7 \% костей всех диких млекопитающих. Охота на птиц и рыбная лов- 
ля хотя и имели место, но они не имели существенного значения.

В РБВ возрастает значение МРС в хозяйственной жизни населения, что может быть связано с благоприятными окружающими условиями для разведения овец и коз, а также с развитием подвижных форм скотоводства. О практике отгонной, а не придомной системы скотоводства на поселении в РБВ свидетельствуют также результаты изучения возрастной схемы забоя домашнего скота.

Изучение стертости жевательной поверхности зубов [40] из нижних челюстей КРС (41 зуб и 5 нижних челюстей) показало, что основная часть КРС на поселении забивалась в возрасте до 6 лет $(91,1$ \%). При этом половина из них забита в самом репродуктивном возрасте от 2,5 до 6 лет (48,9\%), а группа молодых животных до 2,5 лет составляет 42,2 \%. Взрослые и старые особи старше 6 лет 8,7 \%. Обращает на себя внимание большая доля молодых особей, забитых на мясо. При «нормальной» мясной эксплуатации вида забой этой возрастной группы обычно не превышает $25 \%$ [1]. Если молодые животные забиваются в большем количестве при придомном содержании стада, то смена маточного поголовья оказывается невозможной. Но такое возможно, если поселение сезонное или стадо содержится на нем непостоянно. Забой скота в этом случае осуществляется только в определенное время. Кроме этого, при придомном содержании доля животных старше 6 лет обычно составляет не менее 20 \%, а на Турганикском поселении она не превышает $9 \%$. Вероятно, жители поселения практиковали отгонную систему скотоводства.

Выборка челюстей и зубов МРС является самой представительной в коллекции (214 зубов и 7 челюстей). Треть животных съедали еще до достижения ими максимального веса (28,5 \%). Особи продуктивного возраста (от 2 до 6 лет) представлены в кухонных остатках долей в 68,1 \%, а старые животные составили всего лишь 3,4 \%. Для придомного содержания доля животных в первых двух группах слишком высокая, а в последней, напротив, чрезвычайно низкая. По всей видимости, для МРС также практиковалась отгонная система разведения.
Таким образом, Турганикское поселение было или сезонным, или на нем содержалась для мясного потребления лишь некоторая часть поголовья КРС и МРС, а остальной скот выпасался длительное время за его пределами. Данный вывод представляется весьма важным в связи с вопросом формирования самой ямной культуры, представлявшей по своей сути кочевое общество с соответствующей материальной культурой, социальной структурой и духовными ценностями. При этом обращает на себя внимание тот факт, что поселения с материалами репинского типа располагались или на юге Волго-Уральского междуречья (Северный Прикаспий), или на севере междуречья (бассейн рек Самара и Сок). На промежуточной территории таковые неизвестны, что может свидетельствовать о формировании круглогодичного цикла передвижений ямного населения и кочевой, подвижной формы скотоводства на репинском этапе ямной культуры. Вероятно, в летнее время стада перегонялись в северную часть междуречья, на плодородные пастбища Самарского Поволжья и Приуралья. При этом была и другая цель - добыча и плавка руды на Каргалинских рудниках, что отчетливо зафиксировано как на Турганикском поселении, так и на других памятниках ямной культуры в Приуралье [23, с. 293-308].

В силу важности данных проблем в нашем исследовании особое внимание было уделено радиоуглеродному датированию. Не располагая широкими возможностями датирования материалов в лабораториях с АMC технологиями, авторам исследований Турганикского поселения пришлось пойти по пути получения массового количества радиоуглеродных дат сцинтилляционным методом в отечественных лабораториях и их анализа с использованием сравнительного и среднестатистического подходов.

Отбор образцов был сделан послойно с каждых 10 см культурных слоев поселения на разных участках. Радиоуглеродные определения по костям животных из раскопок последних 2 лет осуществлялись М.А. Кульковой в радиоуглеродной лаборатории Российского государственного педагогического университета им. А.И. Герцена под руководством Е.М. Нестерова (г. Санкт-Петербург). Ранее, до раскопок 2014-2015 гг, за неимением других ма- 
териалов было проведено датирование по фрагментам керамики ЭЭ и РБВ в лаборатории г. Киева Н.Н. Ковалюхом и В.В. Скрипкиным [33].

Всего получено 32 радиоуглеродные даты, в том числе 23 по костям животных, по керамике - 9 (табл. 1). В число образцов керамики вошло 2 фрагмента ивановского типа ЭЭ, 4 фрагмента токского типа ЭЭ, 2 фрагмента керамики с расчесами и 1 фрагмент гладкостенной посуды ПБВ.
Bсе даты достаточно компактно образовали 3 группы. Важно отметить, что все группы сложились вокруг ранее известных дат, полученных по керамике, и подтвердили достаточную надежность стратиграфии поселения (см. табл. 2).

І группа сложилась из 4 дат, полученных по керамике ивановского и токского типов, а также из 7 дат, полученных по костям животных, в том числе по костям МРС, КРС и лошади, взятым из слоя ЭЭ (табл. 1, 1-11).

Таблииа 1

\section{Радиоуглеродные даты Турганикского поселения}

\begin{tabular}{|c|c|c|c|c|c|c|}
\hline $\begin{array}{l}\text { № } \\
\Pi / \Pi\end{array}$ & Комплекс & $\begin{array}{l}\text { Шифр } \\
\text { лабор- }\end{array}$ & $\begin{array}{l}\text { Мате- } \\
\text { риал }\end{array}$ & Дата ВР & $\begin{array}{c}\text { Дата ВС } \\
68,2 \%\end{array}$ & $\begin{array}{l}\text { Дата ВC } \\
95,4 \%\end{array}$ \\
\hline 1 & $\begin{array}{l}\text { Уч. } 6 \text { кв. } 126 \text { шт. } 12 \text { кость из } \\
\text { скопления }\end{array}$ & $\mathrm{SPb}-1501$ & лош. & $5816 \pm 80$ & $4769-4556$ & $4846-4466$ \\
\hline 2 & Уч. 8 шт. 14 & $\mathrm{SPb}-1505$ & кж & $6065 \pm 110$ & $5206-4835$ & $5291-4722$ \\
\hline 3 & Уч. 8 шт. 13 & $\mathrm{SPb}-1500$ & мрс & $5908 \pm 80$ & $4898-4694$ & $4992-4582$ \\
\hline 4 & Уч. 9 шт. 11 & $\mathrm{SPb}-1504$ & Кж & $5844 \pm 90$ & $4825-4585$ & $4934-4497$ \\
\hline 5 & Уч. 8 шт. 12 & $\mathrm{SPb}-1499$ & Кж & $5685 \pm 90$ & $4687-4406$ & $4717-4353$ \\
\hline 6 & Уч. 14 кв. 195 шт. 11 & $\mathrm{SPb}-1865$ & крс & $5718 \pm 80$ & $4681-4466$ & $4726-4367$ \\
\hline 7 & Уч. 8 кв. 190 шт. 12 & $\mathrm{SPb}-1861$ & лош. & $5615 \pm 80$ & $4517-4361$ & $4678-4332$ \\
\hline 8 & $\begin{array}{l}\text { Уч. } 5 \text { кв. } 113 \text { шт. } 5 \\
\text { (токский тип) }\end{array}$ & $\mathrm{SPb}-2030$ & кр & $5856 \pm 100$ & $4839-4590$ & $4977-4488$ \\
\hline 9 & Керамика ивановского типа & $\mathrm{Ki} 15067$ & кр & $5660 \pm 70$ & $4590-4440$ & $4690-4350$ \\
\hline 10 & Керамика ивановского типа & Ki 14516 & кр & $5790 \pm 90$ & $4730-4530$ & $4810-4450$ \\
\hline 11 & Керамика токского типа & Ki 14517 & кр & $5830 \pm 70$ & $4780-4590$ & $4850-4500$ \\
\hline 12 & "Уч. 9 шт. 10 & SPb-1496 & кж & $\overline{5300} \pm 85$ & $4237-4005$ & 4328-3971 \\
\hline 13 & Уч. 7 шт. 12 & $\mathrm{SPb}-1491$ & кж & $5288 \pm 70$ & $4231-4005$ & $4320-3971$ \\
\hline 14 & Уч. 7 шт. 13 & $\mathrm{SPb}-1502$ & кж & $5276 \pm 100$ & $4232-3991$ & $4339-3819$ \\
\hline 15 & Уч. 9 шт. 12 & $\mathrm{SPb}-1503$ & крс & $5180 \pm 80$ & $4221-3810$ & $4232-3796$ \\
\hline 16 & Керамика токского типа & Ki 15599 & кр & $5150 \pm 90$ & $4050-3790$ & $4175-3760$ \\
\hline 17 & Керамика токского типа & Ki 15598 & кр & $5230 \pm 90$ & $4230-3960$ & $4266-3914$ \\
\hline 18 & Уч. 7 шт. 9 & SPb-1492 & кж & $5068 \pm 80$ & $3960-3786$ & $4037-3670$ \\
\hline 19 & Уч. 8 шт. 11 & $\mathrm{SPb}-1497$ & крс & $5064 \pm 100$ & $3966-3715$ & $4051-3645$ \\
\hline 20 & Уч. 7 шт. 10 & $\mathrm{SPb}-1493$ & мрс & $4900 \pm 80$ & $3786-3545$ & $3942-3521$ \\
\hline 21 & Уч. 6 шт. 6-8 & $\mathrm{SPb}-1490$ & кж & $4887 \pm 90$ & $3786-3536$ & $3943-3383$ \\
\hline 22 & Уч. 9 шт. 9 & $\mathrm{SPb}-1495$ & кж & $4860 \pm 80$ & $3761-3526$ & $3911-3378$ \\
\hline 23 & Уч. 7 шт. 11 & $\mathrm{SPb}-1498$ & крс & $4800 \pm 70$ & $3656-3386$ & $3706-3376$ \\
\hline 24 & Уч. 8 шт. 10 & $\mathrm{SPb}-1494$ & Кж & $4716 \pm 95$ & $3632-3376$ & $3702-3126$ \\
\hline 25 & $\begin{array}{l}\text { Уч. } 8 \text { кв. } 136 \text { шт. 10-11 } \\
\text { (с расчесами) }\end{array}$ & $\mathrm{SPb}-1507$ & кр & $4681 \pm 100$ & $3631-3363$ & $3654-3308$ \\
\hline 26 & Керамика БВ с расчесами & Ki 15597 & кр & $4710 \pm 80$ & $3630-3370$ & $3654-3346$ \\
\hline 27 & Уч. 14 кв. 191 шт. 9 & $\mathrm{SPb}-1863$ & крс & $4709 \pm 90$ & $3631-3374$ & $3694-3127$ \\
\hline 28 & Уч. 14 кв. 192, 198 шт. 8 & $\mathrm{SPb}-1864$ & мрс & $4693 \pm 70$ & $3626-3373$ & $3637-3359$ \\
\hline 29 & Уч. 13 кв. 188 шт. 9 & $\mathrm{SPb}-1859$ & лош. & $4530 \pm 70$ & $3360-3105$ & $3500-2945$ \\
\hline 30 & Уч. 8 кв. 200 шт. 8 & $\mathrm{SPb}-1860$ & крс & $4490 \pm 100$ & $3351-3030$ & $3498-2909$ \\
\hline 31 & Уч. 14 кв. 185,196 шт. 8 & $\mathrm{SPb}-1866$ & крс & $4737 \pm 70$ & $3633-3381$ & $3643-3370$ \\
\hline 32 & $\begin{array}{l}\text { Уч. } 6 \text { кв. } 118 \text { шт. } 8 \\
\text { (срубного типа) }\end{array}$ & SPb-1506 & кр & $3822 \pm 100$ & $2410-2192$ & $2566-2014$ \\
\hline
\end{tabular}

Примечание. В таблице использованы следующие обозначения: кр - керамика; кж - кости животных; крс - кости крупного рогатого скота; мрс - кости мелкого рогатого скота; лош. - кости лошади. 
Н.Л. Моргунова, Н.В. Рослякова, М.А. Кулькова. Новые данные о хронологии и развитии скотоводства

Таблица 2

Распределение радиоуглеродных дат на Турганикском поселении по глубинам и участкам (в значениях ВР)

\begin{tabular}{|c|c|c|c|c|c|c|c|}
\hline $\begin{array}{c}\text { Глубина } \\
\text { от } 0 \text { штык, см }\end{array}$ & Уч. 1-5 & Уч. 7 & Уч. 6 & Уч. 8 & Уч. 9 & Уч. 13 & Уч. 14 \\
\hline $\begin{array}{c}110-140 / \\
6-8 \text { шт. }\end{array}$ & - & - & $\mathbf{3 8 2 2} \pm \mathbf{1 0 0}$ & - & - & - & $\begin{array}{c}\mathbf{4 7 3 7} \pm \mathbf{7 0} \\
\mathbf{4 6 9 3} \pm \mathbf{7 0}\end{array}$ \\
\hline $\begin{array}{c}140-150 / \\
9 \text { шт. }\end{array}$ & $\mathbf{4 7 1 0} \pm \mathbf{8 0}$ & $\mathbf{5 0 6 8} \pm \mathbf{8 0}$ & $\mathbf{4 8 8 7} \pm \mathbf{9 0}$ & $\mathbf{4 4 9 0} \pm \mathbf{1 0 0}$ & $\mathbf{4 8 6 0} \pm \mathbf{8 0}$ & $\mathbf{4 5 3 0} \pm \mathbf{7 0}$ & $\mathbf{4 7 0 9} \pm \mathbf{9 0}$ \\
\hline $\begin{array}{c}150-160 / \\
10 \text { шт. }\end{array}$ & - & $\mathbf{4 9 0 0} \pm \mathbf{8 0}$ & - & $\begin{array}{c}\mathbf{4 6 8 1} \pm \mathbf{1 0 0} \\
\mathbf{4 7 1 6} \pm \mathbf{9 5}\end{array}$ & $\mathbf{5 3 0 0} \pm \mathbf{8 5}$ & - & - \\
\hline $\begin{array}{c}160-170 / \\
11 \text { шт. }\end{array}$ & $\mathbf{5 2 3 0} \pm \mathbf{9 0}$ & $\mathbf{4 8 0 0} \pm \mathbf{7 0}$ & - & $\mathbf{5 0 6 4} \pm \mathbf{1 0 0}$ & $\mathbf{5 8 4 4} \pm \mathbf{9 0}$ & - & $\mathbf{5 7 1 8} \pm \mathbf{8 0}$ \\
\hline $\begin{array}{c}170-180 / \\
12 \text { шт. }\end{array}$ & $\mathbf{5 8 5 6} \pm \mathbf{1 0 0}$ & $\mathbf{5 2 8 8} \pm \mathbf{7 0}$ & - & $\mathbf{5 6 1 5} \pm \mathbf{8 0}$ & $\mathbf{5 1 8 0} \pm \mathbf{8 0}$ & - & - \\
\hline $\begin{array}{c}180-190 / \\
13 \text { шт. }\end{array}$ & $\mathbf{5 7 9 0} \pm \mathbf{9 0}$ & $\mathbf{5 2 7 6} \pm \mathbf{1 0 0}$ & - & $\mathbf{5 9 0 8} \pm \mathbf{8 0}$ & - & - & - \\
\hline $\begin{array}{c}187-197 / \\
14 \text { шт. }\end{array}$ & $\mathbf{5 8 3 0} \pm \mathbf{7 0}$ & - & $\mathbf{5 8 1 6} \pm \mathbf{8 0}$ & $\mathbf{6 0 6 5} \pm \mathbf{1 1 0}$ & - & - & - \\
\hline
\end{tabular}

Их значения возрастают от $5615 \pm 80 \mathrm{BP}$ до $6065 \pm 110$ ВР. Суммирование вероятностей калиброванных значений проводилось в одну сигму с отказом от самой ранней и от самой поздней даты для получения более узкого интервала. В итоге для данной группы сформировался интервал в пределах 4898-4440 cal BC (рис. 6). Все ${ }^{14} \mathrm{C}$ даты, полученные по керамике и по костям животных, имеют близкие, вернее совпадающие значения.

Полученный интервал соответствует хронологии Хвалынских могильников, где содержится керамика, аналогичная сосудам из слоя Турганикского поселения [38, с. 380), а также материалам хвалынского типа на поселениях Самарского Поволжья [10, с. 270]. В слое поселения найден обломок браслета из мергеля, идентичный находкам в Нальчикском могильнике. Одно из погребений последнего имеет ${ }^{14} \mathrm{C}$ дату, полученную на $\mathrm{AMC}$,$5910 \pm 45$ BP (GrA 24442) [8, c. 63].

Таким образом, первое поселение в устье р. Турганик было основано населением, оставившим керамические материалы ивановского и хвалынского типов самарской культуры. К этому же времени относится и наиболее архаичная часть керамики токского типа.

Во II хронологическую группу включено $6{ }^{14}$ С дат, расположившихся в интервале 4237 $3790 \mathrm{cal} \mathrm{BC} \mathrm{(см.} \mathrm{табл.} \mathrm{1,} \mathrm{12-17).} \mathrm{В} \mathrm{эту} \mathrm{группу}$ входят 2 даты, полученные по керамике токского типа. Посуда данного типа на Турганикском поселении типологически и морфологи- чески неоднородна. Видимо, имеющиеся ${ }^{14} \mathrm{C}$ данные показывают 2 хронологических этапа в ее эволюции. Первый этап связан с периодом ее сосуществования с гончарной традицией воротничковой посуды ивановского типа, а второй отражает продолжение эволюции токского типа, связанного с лесостепными традициями в период позднего энеолита во второй половине $\mathrm{V}$ тыс. до н. э., когда воротничковый тип гончарства уже изжил себя. Палеопочведческие исследования, проведенные во время последних раскопок, подтвердили ${ }^{14} \mathrm{C}$ данные, показав, что в нарастании почвенных отложений нижнего слоя был значительный перерыв, связанный с сильными паводками, не позволявшими людям проживать на данном месте.

Таким образом, было установлено, что жители Турганикского поселения в годы наступления сильных наводнений могли временно оставлять данное место и переселяться на более высокий берег р. Ток, на Ивановское поселение. Этот вывод подтверждают данные типологического и технико-технологического анализа керамики обоих поселений, который позволяет утверждать, что первоначально поселение возникло в устье р. Турганик, а затем на месте Ивановского поселения. Вторично на Турганик вернулись в период позднего энеолита, и это население сохраняло токскую традицию гончарства.

Со вторым периодом поселения связано появление здесь явно «импортной» керамики суртандинского и новоильинского типов. 
Об этом свидетельствуют имеющиеся на сегодняшний день радиоуглеродные данные по культурам с геометрической орнаментацией в Зауралье [34, с. 39], а также последние данные датирования материалов новоильинского типа эпохи энеолита Прикамья [13]. На Турганикском поселении эта керамика обособлена на северной окраине поселка, где найдена керамика только токского типа.

III хронологическая группа представлена $14{ }^{14} \mathrm{C}$ датами, из них по керамике с расчесами -2 ; по костям животных, включая кости домашних видов, -12 . Значения дат возрастают от $4530 \pm 30$ до $5064 \pm 100$ ВР. Калиброванный интервал в одну сигму устанавливается в пределах 3966-3100 cal BC, или 38003360 cal BC (с отказом от самой ранней и от самой поздней дат).

Таким образом, массовое датирование костей животных и керамики репинского типа Турганикского поселения позволило подтвердить удревнение раннего этапа ямной культуры, что ранее утверждалось по данным ${ }^{14} \mathrm{C}$ датирования погребальных памятников [22; 23 , c. 179-186]. В этом же интервале находится дата, полученная нами в результате ${ }^{14} \mathrm{C}$ датирования из кургана 7 могильника Переволоцкий, который упоминался выше в связи с находкой в нем сосуда типа хума, аналогичного турганикским образцам. Ее значение: $4885 \pm 120$ BP (SPb-1706), 3895-3607 cal BC.

Результаты. В результате комплексных исследований Турганикского поселения получены ценные сведения по истории Южного Приуралья - в эпоху энеолита (развитой и поздний этапы самарской культуры) и в раннем бронзовом веке (ранний этап ямной культуры). Установлена культурная и хронологическая последовательность и преемственность между тремя крупными периодами развития этих культурных образований, в том числе в скотоводческой направленности хозяйства.

Первое поселение (4898-4440 cal BC) было основано в устье р. Турганик населением самарской культуры (керамика ивановского и токского типа). Они представляют местную линию развития, идущую от традиций эпохи неолита и раннего, съезжинского этапа самарской культуры. На данном этапе суще- ствования поселения зафиксированы активные контакты самарской и хвалынской культур. С влиянием хвалынской культуры связано появление первого металла, пока импортного. Жители поселка занимались преимущественно скотоводством, подсобную роль играли охота и рыболовство.

Второй крупный период (42373790 cal BC) в жизни поселения связан с пребыванием здесь населения, изготавливавшего исключительно керамику токского типа. При этом зафиксированы контакты с культурами Прикамья (новоильинская культура) и Зауралья (суртандинская культура).

Третий период (3800-3360 cal BC) относится к раннему репинскому этапу ямной культуры. В данный период, вероятно, поселение было сезонным, однако, судя по мощности культурного слоя и ${ }^{14} \mathrm{C}$ датам, оно функционировало достаточно продолжительное время. Развивалось местное металлопроизводство на базе Каргалинского месторождения медной руды, расположенного примерно в 100 км выше по течению р. Ток от Турганикского поселения. Основную роль в хозяйстве играло скотоводство в подвижно-кочевой форме.

Выше слоя РБВ лежат 4 слоя мощных балластовых отложений, образовавшиеся в результате паводковых наносов, начиная с раннего этапа ПБВ, когда наступило похолодание и установился более влажный период. С этого времени данное место не использовалось для постоянного проживания, но в окрестностях Турганикского поселения известны несколько поселений абашевского и срубного времени, в том числе мощный слой на Ивановском поселении.

\section{ПРИМЕЧАНИЕ}

${ }^{1}$ Работа выполнена в рамках проекта 33.1389.2017 государственного задания Министерства науки и высшего образования Российской Федерации, а такжегранта РФФИ№ 40031 «Древности».

The work was carried out within project 33.1389.2017 of the state task of the Ministry of Science and Higher Education of the Russian Federation, as well as Russian Foundation for Basic Research grant no. 40031 "Antiquities". 


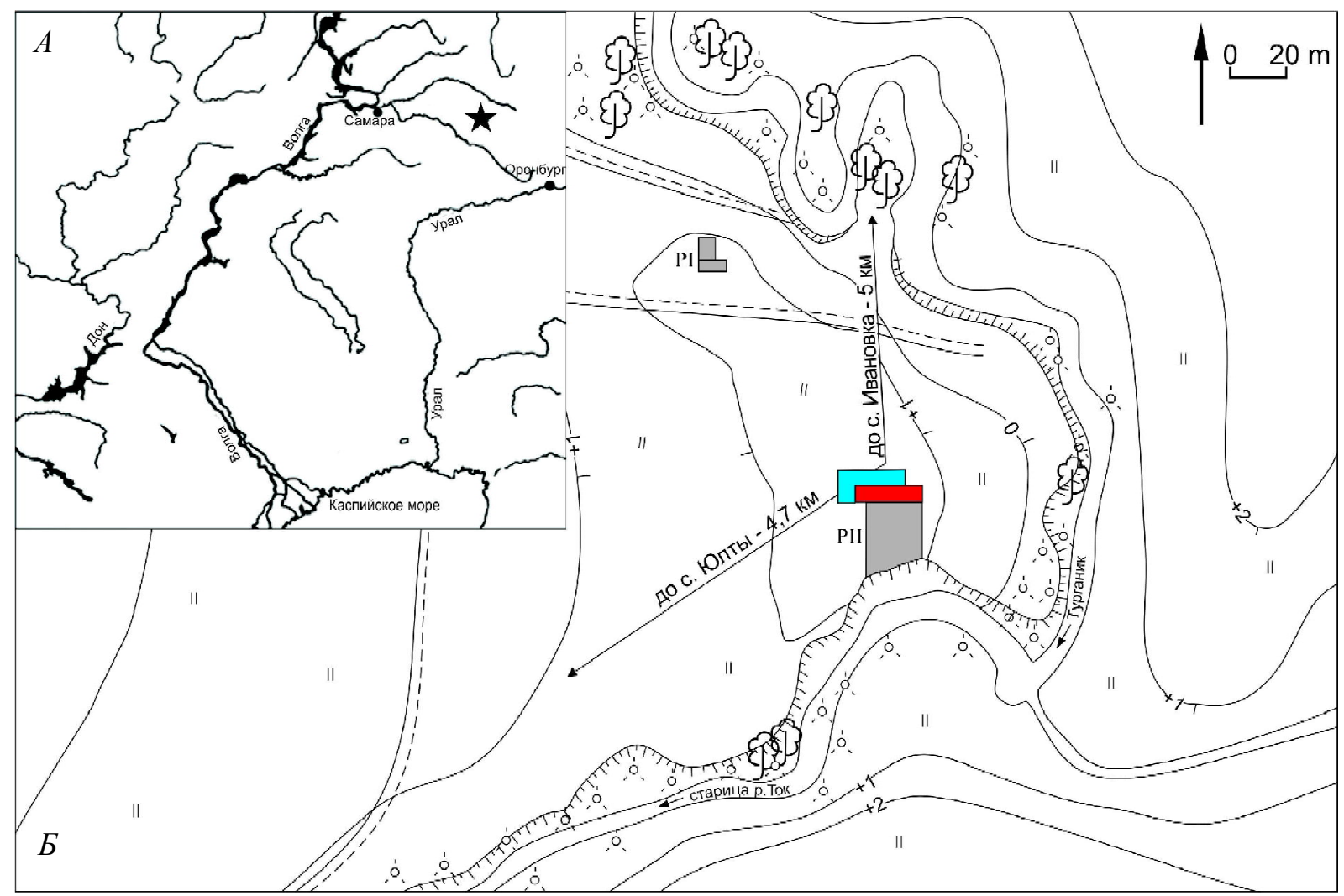

Рис. 1. Карта Волго-Уральского междуречья и расположения Турганикского поселения $(A)$. План Турганикского поселения (Б)

Fig. 1. Map of the Volga-Ural interfluve and the location of Turganik settlement $(A)$. Plan of Turganik settlement $(B)$ 


\section{АРХЕОЛОГИЯ}

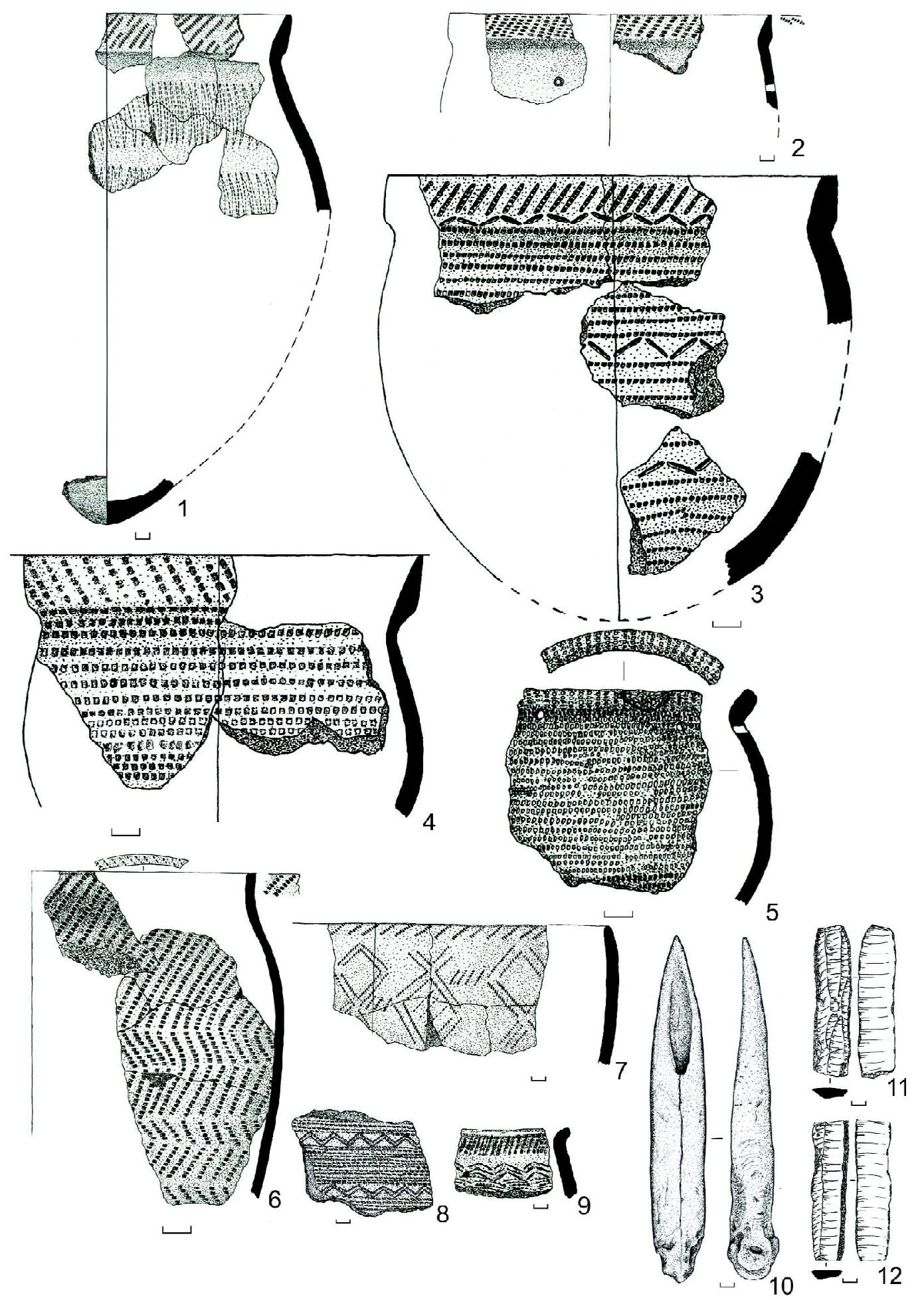

Рис. 2. Находки из слоя ЭЭ Турганикского поселения:

1-3 - керамика ивановского типа; 4-5 - керамика хвалынско-ивановского типа; 6 - керамика токского типа;

7 - керамика новоильинского типа; 8-9 - керамика суртандинского типа; 10 - наконечник копья из кости лошади; 11-12 - пластины из кремня

Fig. 2. Findings from the Eneolithic layer of Turganik settlement:

1-3 - ceramics of the Ivanovo type; 4-5 - ceramics of the Khvalynian-Ivanovo type; 6 - ceramics of the Tokskiy type;

7 - ceramics of the Novoilinskiy type; $8-9$ - ceramics of the Surtandinskiy type; 10 - spearhead made of horse bone; $11-12$ - plates made of flint 
Н.Л. Моргунова, Н.В. Рослякова, М.А. Кулькова. Новые данные о хронологии и развитии скотоводства

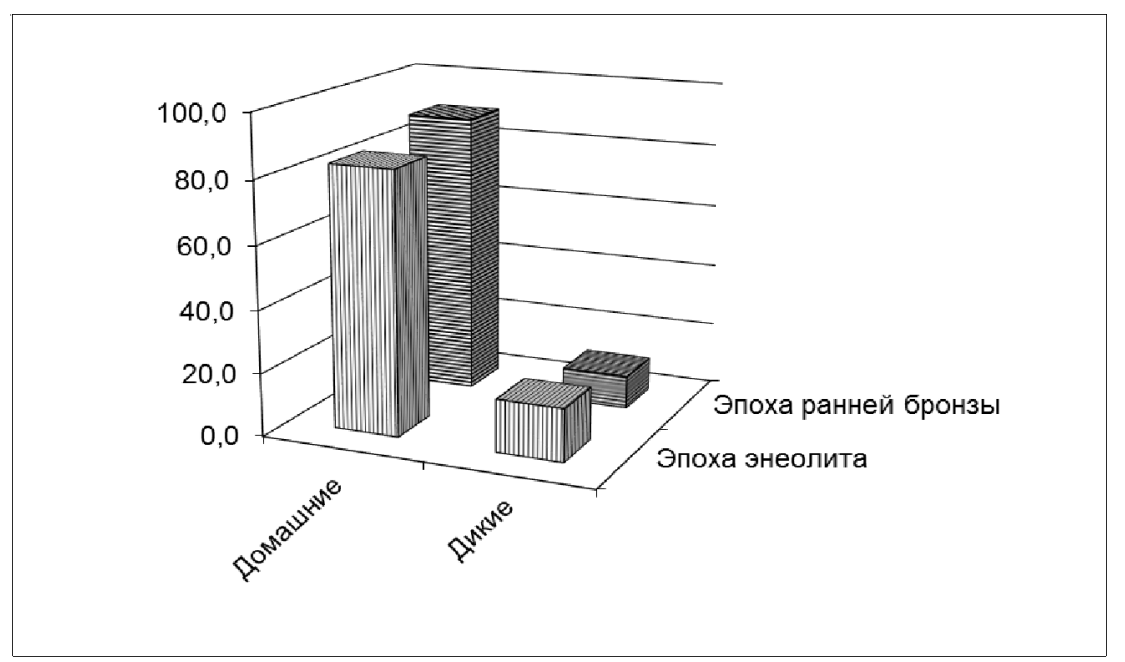

Рис. 3. Соотношение костей домашних и диких видов животных на Турганикском поселении, \%

Fig. 3. The ratio of bones of domestic and wild species in Turganik settlement, $\%$

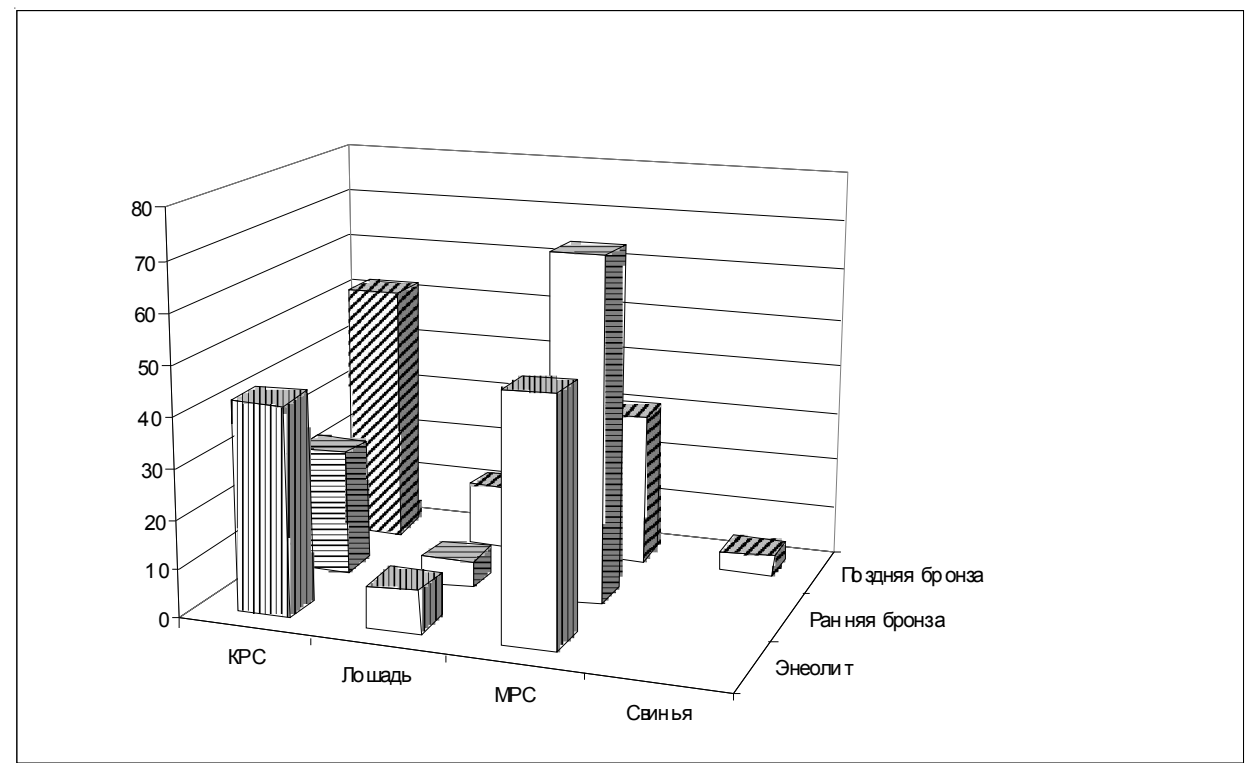

Рис. 4. Соотношение костей домашних видов животных в коллекции Турганикского поселения и в эпоху поздней бронзы в Урало-Поволжье, \%

Fig. 4. The ratio of bones of domestic species in the collection of Turganik settlement and in the Late Bronze Age in the Ural-Volga region, \% 

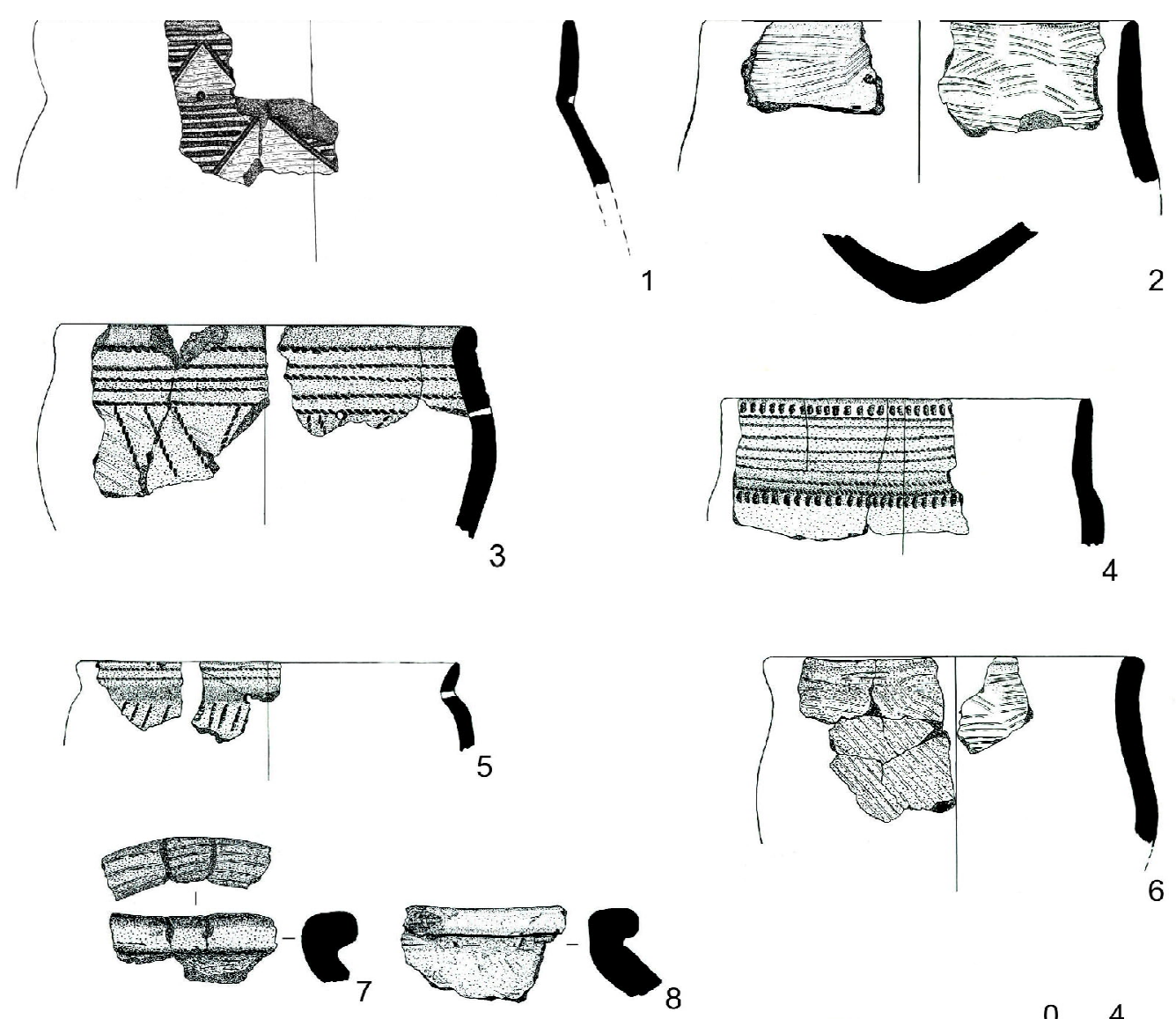

6
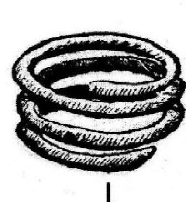

1
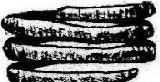

9
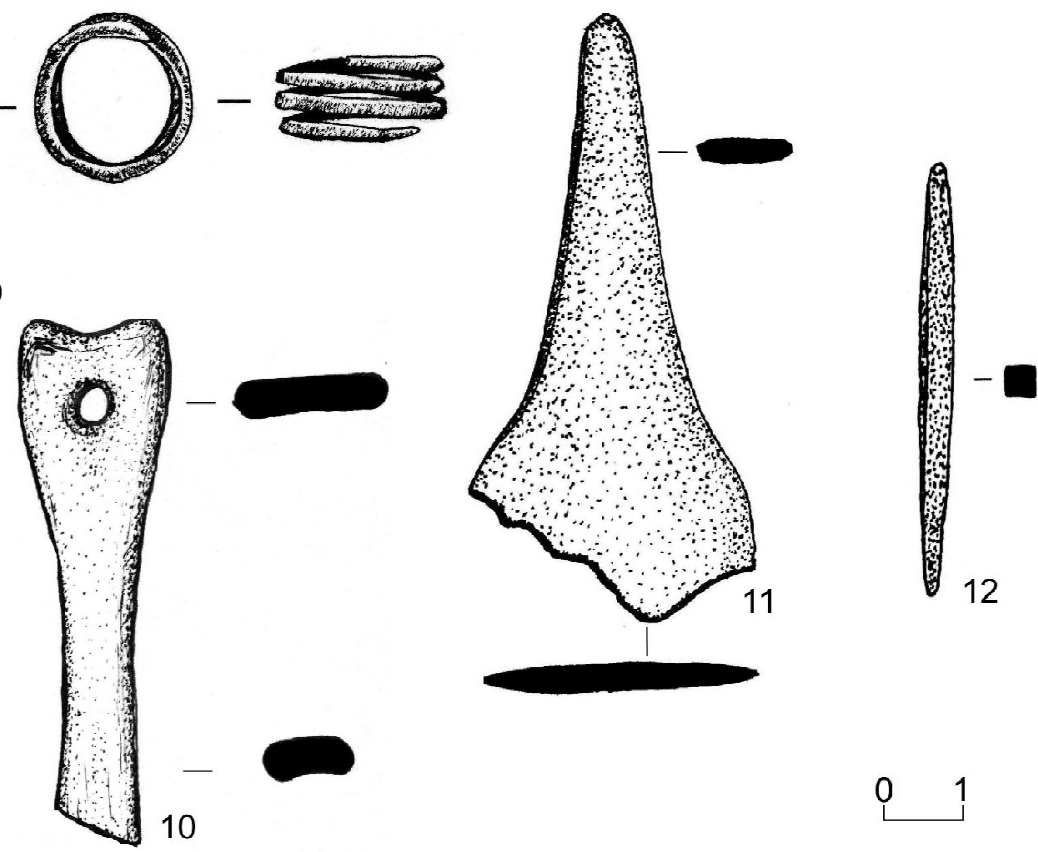

Рис. 5. Материалы РБВ Турганикского поселения:

1-8- керамика; 9, 11-12- медь; 10 - кость

Fig. 5. Materials of the Early Bronze Age of Turganik settlement:

1-8-ceramics; 9, 11-12-copper; 10 - bone 
Н.Л. Моргунова, Н.В. Рослякова, М.А. Кулькова. Новые данные о хронологии и развитии скотоводства

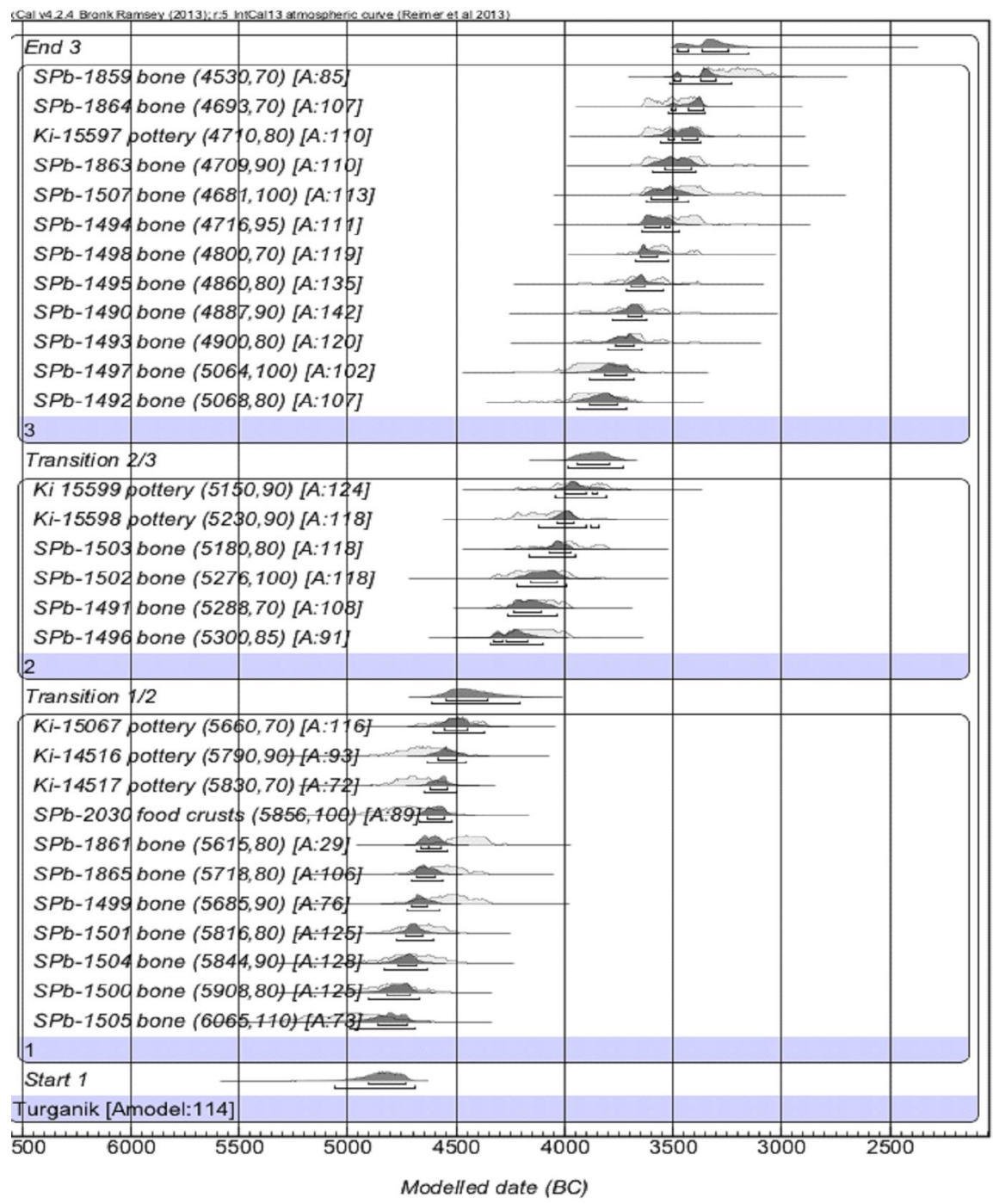

Рис. 6. Калиброванная шкала радиоуглеродных дат (Турганикское поселение)

Fig. 6. Calibrated scale of radiocarbon dates (Turganik settlement) 


\section{СПИСОК СОКРАЩЕНИЙ} буржья

АПО - Археологические памятники Орен-

АСГЭ - Археологические сообщения Государственного Эрмитажа.

ГИМ - Государственный исторический музей, г. Москва.

КСИА - Краткие сообщения Института археологии.

$C A(P A)-$ Советская археология (Российская археология).

СНЦ РАН - Самарский научный центр РАН.

\section{СПИСОК ЛИТЕРАТУРЫ}

1. Антипина, Е. Е. Состав древнего стада домашних животных: логические аппроксимации / Е. Е. Антипина // OPUS: междисциплинарные исследования в археологии. - М. : Параллели, 2008. Вып. 6. - С. 67-85.

2. Барынкин, П. П. Северный Прикаспий в период энеолита и ранней бронзы / П. П. Барынкин // Вопросы археологии Поволжья. - Самара : СНЦ РАН ; СамГПУ, 2003. - Вып. 3. - С. 47-60.

3. ван дер Плихт, Й. Радиоуглеродное датирование: хронология археологических культур и резервуарный эффект / Й. ван дер Плихт, Н. И. Шишлина, Э. П. Зазовская. - М. : [б. и.], 2016. - 112 с. (Труды ГИМ ; вып. 203).

4. Васильев, И. Б. Энеолит Поволжья. Степь и лесостепь / И. Б. Васильев. - Куйбышев : Изд-во КГПИ, 1981.-127 с

5. Васильев, И. Б. Могильник у с. Съезжее на р. Самаре / И. Б. Васильев, Г. И. Матвеева // СА. 1979. - № 4. - С. 147-166.

6. Дегтярева, А. Д. История металлопроизводства Южного Зауралья в эпоху бронзы / А. Д. Дегтярева. - Новосибирск : Наука, 2010. - 162 с.

7. Кияшко, В. Я. Рогатые амулеты раннего бронзового века / В. Я. Кияшко // Известия Ростовского областного музея краеведения. - Ростов н/Д : [б. и.], 1989. - Вып. 6. - С. 76-88.

8. Кореневский, С. Н. Рождение кургана (погребальные памятники энеолитического времени Предкавказья и Волго-Донского междуречья) / С. Н. Кореневский. - М. : Таус, 2012. - 256 с.

9. Коробкова, Г. Ф. Поселение Михайловка эталонный памятник древнеямной культуры (экология, жилища, орудия труда, системы жизнеобеспечения, производственная структура) / Г. Ф. Коробкова, О. Г. Шапошникова. - СПб. : ИИМК РАН, 2005. $-326 \mathrm{c}$.

10. Королев, А. И. К вопросу о хронологии и периодизации энеолита степного и лесостепного
Поволжья / А. И. Королев, А. А. Шалапинин // Известия СНЦ РАН. -2014. - Т. 16, № 3. - С. 266-275.

11. Кузнецов, П. Ф. Датировка памятника у Репина Хутора и хронология культурно-родственных материалов эпохи ранней бронзы степной зоны Восточной Европы / П. Ф. Кузнецов // РА. - 2013. № 1. - C. 13-21.

12. Л Лагодовська, Р. Ф. Михайлівське поселення / Р. Ф. Лагодовська, О. Г. Шапошникова, М. Л. Макаревич. - Киів : Наукова думка, 1962. - 247 с.

13. Лычагина, Е. Л. Ранний энеолит Прикамья. Вопросы хронологии новоильинской культуры / Е. Л. Лычагина // Проблемы периодизации и хронологии эпохи раннего металла Восточной Европы. - СПб. : ИИМК РАН, 2013. - С. 153-156.

14. Матюшин, Г. Н. Энеолит Южного Урала / Г. Н. Матюшин. - М. : Наука, 1982. - 326 с.

15. Мерперт, Н. Я. Древнейшие скотоводы Волжско-Уральского междуречья / Н. Я. Мерперт. М. : Наука, 1974. - 166 с.

16. Мерперт, Н. Я. Проблемы энеолита степи и лесостепи Восточной Европы / Н. Я. Мерперт // Энеолит Восточной Европы. - Куйбышев : Изд-во КГПИ, 1980.- С. 3-26.

17. Мимоход, Р. А. Курганы эпохи бронзыраннего железного века в Саратовском Поволжье / Р. А. Мимоход. - М. : Таус, 2009. - 292 с. - (Материалы охранных археологических исследований ; т. 10).

18. Моргунова, Н. Л. Турганикская стоянка и некоторые проблемы самарской культуры / Н. Л. Моргунова // Эпоха меди Восточной Европы. - Куйбышев : Изд-во КГПИ, 1984. - С. 58-78.

19. Моргунова, Н. Л. Энеолитические комплексы Ивановской стоянки / Н. Л. Моргунова // Неолит и энеолит Северного Прикаспия. - Куйбышев : Изд-во КГПИ, 1989. - С. 118-135.

20. Моргунова, Н. Л. Неолит и энеолит юга лесостепи Волго-Уральского междуречья / Н. Л. Моргунова. -Оренбург : Юж. Урал, 1995. - 222 с.

21. Моргунова, Н. Л. Энеолит Волжско-Уральского междуречья / Н. Л. Моргунова. - Оренбург : Изд-во ОГПУ, 2011. - 220 с.

22. Моргунова, Н. Л. Радиокарбонная хронология ямной культуры Волжско-Уральского междуречья / Н. Л. Моргунова // КСИА. - 2013. Вып. 230.- С. 5-23.

23. Моргунова, Н. Л. Приуральская группа памятников в системе волжско-уральского варианта ямной культурно-исторической области / Н. Л. Моргунова. - Оренбург : Изд-во ОГПУ, 2014. - 348 с.

24. Наумов, И. Н. С14 хронология и факторы распространения навыков доместикации лошади на территории Восточной Европы / И. Н. Наумов // Происхождение и распространение колесничества. - Луганск : Шлях, 2008. - С. 9-19. 
25. Переволоцкий курганный могильник в Оренбургской области: предварительные результаты исследования / Н. Л. Моргунова, А. А. Евгеньев, Е. А. Крюкова, Л. В. Купцова, П. В. Харламов, И. А. Файзуллин // АПО. - Оренбург : Университет, 2016. - Вып. 12. - С. 21-51.

26. Петренко, А. Г. Становление и развитие основ животноводческой деятельности в истории народов Среднего Поволжья и Предуралья / А. Г. Петренко. - Казань : Ин-т истории АН Республика Татарстан, 2007. - 144 с. - (Археология евразийских степей ; вып. 3).

27. Пряхин, А. Д. Новые материалы по неолиту и энеолиту Среднего Дона с Шиловского поселения / А. Д. Пряхин, А. Т. Синюк // Энеолит Восточной Европы. - Куйбышев : Изд-во КГПИ, 1980. C. 73-92.

28. Салугина, Н. П. Результаты технико-технологического анализа керамики репинского облика стоянки Турганик (предварительные итоги) / Н. П. Салугина // АПО. - Оренбург : Университет, 2016. - Вып. 12. - С. 60-70.

29. Салугина, Н. П. Крупнотарные сосуды бронзового века Турганикского поселения в Оренбургской области / Н. П. Салугина, Н. Л. Моргунова, М. А. Турецкий // Самарский научный вестник. - 2016. - № 4 (17). - С. 91-98.

30. Синицин, И. В. Памятники Нижнего Поволжья и их связь с Приднепровьем / И. В. Синицын // КСИА. - Киев : Наукова думка, 1957. - Вып. 7. C. $32-35$.

31. Турганикское поселение в Оренбургской области / Н. Л. Моргунова, И. Н. Васильева, Н. А. Кулькова, Н. В. Рослякова, Н. П. Салугина, М. А. Турецкий , А. А. Файзуллин, О. С. Хохлова. Оренбург : Изд. центр ОГАУ, 2017. - 300 с.

32. Турецкий, М. А. Некоторые проблемы изучения ямной культуры Волго-Уральского региона / М. А. Турецкий // Проблемы изучения ямной культурно-исторической области. - Оренбург : Изд-во ОГПУ, 2006.-С. 94-100.

33. Хронологическое соотношение энеолитических культур Волго-Уральского региона в свете радиоуглеродного датирования / Н. Л. Моргунова, А. А. Выборнов, Н. Н. Ковалюх, В. В. Скрипкин // РA. - 2010. - № 4. - С. 19-28.

34. Хронология энеолита и эпохи ранней бронзы в Уральском регионе / В. С. Мосин, А. В. Епимахов, А. А. Выборнов, А. И. Королев // Археология, этнография и антропология Евразии. - 2014. № 4 (60). - С. 41-53.

35. Цалкин, В. И. Древнейшие домашние животные Восточной Европы / В. И. Цалкин. - М. : Наука, 1970. - 270 c.

36. Черных, Е. Н. Радиоуглеродная хронология древнеямной общности и истоки курганных культур / Е. Н. Черных, Л. Б. Орловская // РА. 2004. - № 1. - С. 84-99.

37. Шилов, В. П. Проблемы освоения степей Нижнего Поволжья в эпоху бронзы / В. П. Шилов // АСГЭ. - Л. : Изд-во Гос. Эрмитажа, 1964. - № 6. C. 86-102.

38. Шишлина, Н. И. Северо-Западный Прикаспий в эпоху бронзы (V-III тыс. до н. э.) / Н. И. Шишлина. - М. : ГИМ, 2007. - 400 с.

39. Юдин, А. И. Варфоломеевская стоянка и неолит степного Поволжья / А. И. Юдин. - Саратов : Науч. кн., 2004. -199 с.

40. Grant, A. The Use of Tooth Wear as a Guide to the Age of Domestic Ungulates / A. Grant // Ageing and Sexing Animal Bones from Archaeological Sites / ed. by B. Wilson, C. Grigson, S. Payne. - Oxford : BAR(British Series) 109, 1982. - P. 91-108.

\section{REFERENCES}

1. Antipina E.E. Sostav drevnego stada domashnikh zhivotnyikh: logicheskie approksimatsii [Composition of Herd of Domestic Ungulates: Logical Approximations]. OPUS: mezhdistsiplinarnye issledovaniya $v$ arkheologii [OPUS: Interdisciplinary Studies in Archaeology]. Moscow, Paralleli Publ., 2008, iss.6, pp. 67-85.

2. Barynkin P.P. Severnyy Prikaspiy v period eneolita i ranney bronzy [Northern Caspian in the Period of the Eneolithic and Early Bronze Age]. Voprosy arkheologii Povolzhya. Samara, SNTs RAN, SamGPU, 2003, iss. 3, pp. 47-60.

3. J. van der Plicht, Shishlina N.I., Zazovskaya E.P. Radiouglerodnoe datirovanie: khronologiya arkheologicheskikh kultur i rezervuarnyy effekt [Radiocarbon Dating: Chronology of Archaeological Cultures and Reservoir Effect]. Moscow, 2016. 112 p. (Trudy GIM, vyp. 203).

4. Vasilev I.B. Eneolit Povolzhya [The Eneolithic of the Volga Region]. Kuybyshev, Izd-vo KGPI, 1981. 127p.

5. Vasilev I.B., Matveeva G.I. Mogilnik u s. Sezzhee na r. Samare [The Burial Ground near Sezzhee Village on the Samara River]. SA, 1979, no. 4, pp. 147-166.

6. Degtyareva A.D. Istoriya metalloproizvodstva Yuzhnogo Zauralya v epochu bronzy [History of Metal Production of the Southern Transurals in the Bronze Age]. Novosibirsk, Nauka Publ., 2010. 162 p.

7. Kiyashko V.Ya. Rogatye amulety rannego bronzovogo veka [Horned Amulets of the Early Bronze Age]. Izvestiya Rostovskogo oblastnogo muzeya kraevedeniya. Rostov-on-Don, 1989, iss. 6, pp. 76-88.

8. Korenevskiy S.N. Rozhdenie kurgana (pogrebalnye pamyatniki eneoliticheskogo vremeni 
Predkavkazya i Volgo-Donskogo mezhdurechya [Birth of the Mound (Burial Sites of the Eneolithic Time of the Ciscaucasia and the Volga-Don Interfluve)]. Moscow, Taus Publ., 2012. 256 p.

9. Korobkova G.F, Shaposhnikova O.G. Poselenie Mikhaylovka - etalonnyy pamyatnik drevneyamnoy kultury (ekologiya, zhilishcha, orudiya truda, sistemy zhizneobespecheniya, proizvodstvennaya struktura) [The Settlement of Mikhailovka as a Reference Site of the Pit Grave Culture (Ecology, Dwellings, Tools, Life Support Systems, Production Structure)]. Saint Petersburg, IIMK RAN, 2005. 326 p.

10. Korolev A.I, Shalapinin A.A. K voprosy o chronologii i periodizatsii eneolita stepnogo i lesostepnogo Povolzhya [The Question of the Chronology and Periodization of the Eneolithic Steppe and Forest-Steppe of the Volga Region]. Izvestiya SNTS $R A N$ [Izvestia of Samara Scientific Center of the Russian Academy of Sciences], 2014, vol. 16, no. 3, pp. 266-275.

11. Kuznetsov P.F. Datirovka pamyatnika y Repina Khytora $i$ khronologiya kulturnorodstvennykh materialov epokhi ranney bronzy stepnoy zony Vostochnoy Evropy [Dating of the Site at Repin Khutor and the Chronology of Cultural and Related Materials from the Early Bronze Age of the Steppe Zone of Eastern Europe]. RA, 2013, no. 1, pp. 13-21.

12. Lagodovska R.F., Shaposhnikova O.G., Makarevich M.L. Mikhailivske poselennya [Michailovka Settlements]. Kiev, Naukova dumka Publ., 1962. 247 p.

13. Lychagina E.L. Ranniy eneolit Prikamya. Voprosy khronologii novoilinskoy kultury [Early Eneolithic of the Kama Region. Issues of the Chronology of the Novoilinskaya Culture]. Problemy periodizatsii $i$ khronologii epokhi rannego metalla Vostochnoy Evropy [Problems of Periodization and Chronology of the Early Metal Era of Eastern Europe]. Saint Petersburg, IIMK RAN, 2013, pp. 153-156.

14. Matyushin G.N. Eneolit Yuzhnogo Urala [The Eneolothic Age of the South Urals]. Moscow, Nauka Publ., 1982. 326 p.

15. Merpert N.Ya. Drevneyshie skotovody Volzhsko-Uralskogo mezhdurechya [The Ancient Cattle Breeders of the Volga-Ural Interfluve]. Moscow, Nauka Publ. 1974. 166 p.

16. Merpert N.Ya. Problemy eneolita stepi i lesostepi Vostochnoy Evropy [Problems of the Eneolithic Steppe and Forest-Steppe of Eastern Europe]. Eneolit Vostochnoy Evropy [The Eneolithic of Eastern Europe]. Kuybyshev, Izd-vo KGPI, 1980, pp. 3-26.

17. Mimokhod R.A. Kurgany epokhi bronzyrannego zheleznogo veka $v$ Saratovskom Povolzhye [Barrows of the Bronze Age - the Early Iron Age in the Saratov Volga Region]. Moscow, Taus Publ., 2009.
292 p. (Materialy okhrannykh arkheologicheskikh issledovaniy, t. 10 [Materials of Security Archaeological Research, vol. 10]).

18. Morgunova N.L. Turganikskaya stoyanka i nekotorye problemy samarskoy kultury [Turganinskaya Site and Some Problems of the Samara Culture]. Epokha medi Vostochnoy Evropy [The Copper Era of Eastern Europe]. Kuybyshev, Izd-vo KGPI, 1984, pp. 58-78.

19. Morgunova N.L. Eneoliticheskie kompleksy Ivanovskoy stoyanki [Eneolithic complexes of Ivanovskaya Site]. Neolit i eneolit Severnogo Prikaspiya [The Neolithic and Eneolithic of the Northern Caspian Region]. Kuybyshev, Izd-vo KGPI, 1989, pp. 118-135.

20. Morgunova N.L. Neolit i eneolit yuga lesostepi Volgo-Uralskogo mezhdurechya [The Neolithic and Eneolithic of the South of the ForestSteppe of the Volga-Ural Interfluve]. Orenburg, Yuzhnyy Ural Publ., 1995. 222 p.

21. Morgunova N.L. Eneolit VolzhskoUralskogo mezhdurechya [The Eneolithic of the Volga-Ural Interfluve]. Orenburg, Izd-vo OGPU, 2011. 220 p.

22. Morgunova N.L. Radiokarbonnaya khronologiya yamnoy kultury Volzhsko-Uralskogo mezhdurechya [Radiocarbon Chronology of the Pit Culture of the Volga-Ural Interfluve]. KSIA [Brief Communications of the Institute of Archaeology], 2013, iss. 230, pp. 5-23.

23. Morgunova N.L. Priuralskaya gruppa pamyatnikov $v$ sisteme volzhsko-uralskogo varianta yamnoy kulturno-istoricheskoy oblasti [The Cis-Ural Group of the Archaeological Sites in the System of Volga-Ural Variant of Pit-Grave Cultural and Historical Area]. Orenburg, OGPU Publ., 2014. 348 p.

24. Naumov I.N. C14 khronologiya i faktory rasprostraneniya navykov domestikatsii loshadi na territorii Vostochnoy Evropy [C14 Chronology and Factors of Distribution of Habits of Horse Domestication in the Territory of Eastern Europe]. Proiskhozhdenie i rasprostranenie kolesnichestva [Origin and Distribution of Chariotism]. Lugansk, Shlyakh Publ., 2008, pp. 9-19.

25. Morgunova N.L., EvgenevA.A., Kryukova E.A., Kuptsova L.V., Kharlamov P.V., Fayzullin I.A. Perevolotskiy kurgannyy mogilnik v Orenburgskoy oblasti: predvaritelnye rezultaty issledovaniya [Perevolotskiy Burial Mound in Orenburg Region: Preliminary Results of the Study]. Arkheologicheskie pamyatniki Orenburzhya [Archaeological Sites of the Orenburg Region]. Orenburg, Universitet Publ., 2016, iss. 12, pp. 21-51.

26. Petrenko A.G. Stanovlenie i razvitie osnov zhivotnovodcheskoy deyatelnosti $v$ istorii narodov Srednego Povolzhya i Preduralya [The Formation and 
Development of the Livestock Breeding in the History of the Peoples in the Middle Volga and Ural Region]. Kazan, Institut istorii AN Respublika Tatarstan, 2007. 144 p. (Arkheologiya evraziyskikh stepey, vyp. 3 [Archeology of the Eurasian Steppes, iss. 3]).

27. Pryakhin A.D., Sinyuk A.T. Novye materialy po neolitu i eneolitu Srednego Dona s Shilovskogo poseleniya [New Materials on the Neolithic and Eneolithic of the Middle Don from Shilovskoe Settlement]. Eneolit Vostochnoy Evropy [The Eneolithic of Eastern Europe]. Kuybyshev, Izd-vo KGPI, 1980, pp. 73-92.

28. Salugina N.P. Rezultaty tekhnikotekhnologicheskogo analiza keramiki repinskogo oblika stoyanki Turganik (predvaritelnye itogi) [Results of Technical and Technological Analysis of the Repin's Ceramics of Turganik Site (Preliminary Results)]. Arkheologicheskie pamyatniki Orenburzhya [Archaeological Sites of the Orenburg Region]. Orenburg, Universitet Publ., 2016, iss. 12, pp. 60-70.

29. Salugina N.P., Morgunova N.L., TuretskiyM.A. Krupnotarnye sosudy bronzovogo veka Turganikskogo poseleniya v Orenburgskoy oblasti [Large-Volume Vessels of the Bronze Age of Turganikskiy Settlement in Orenburg Region]. Samarskiy nauchnyy vestnik [Samara Journal of Science], 2016, no. 4 (17), pp.91-98.

30. Sinitsin I.V. Pamyatniki Nizhnego Povolzhya i ikh svyaz s Pridneprovyem [Monuments of Lower Volga Area and Their Communication with Pridneprovye]. KSIA [Brief Communications of the Institute of Archaeology]. Kiev, Naukova dumka Publ., 1957, pp. 32-35.

31. Morgunova N.L, Vasileva I.N, Kulkova M.A, Roslyakova N.V, Salugina N.P, Turetskiy M.A, Fayzullin A.A, Khokhlova O.S. Turganikskoe poselenie $v$ Orenburgskoiy oblasti [Turganik Settlement in Orenburg Region]. Orenburg, Izd-vo OGPU, 2017.300 p.

32. Turetskiy M.A. Nekotorye problemy izucheniya yamnoy kultury Volgo-Uralskogo regiona [Some Problems of Studying the Pit Grave Culture of the Volga-Ural Region]. Problemy izucheniya yamnoy kul turno-istoricheskoy oblasti [Problems of Studying the Pit Cultural and Historical Area]. Orenburg, Izd-vo OGPU, 2006, pp. 94-100.

33. Morgunova N.L., Vybornov A.A., Kovalyukh N.N., Skripkin V.V. Khronologicheskoe sootnoshenie eneoliticheskikh kultur Volgo-Uralskogo regiona $\mathrm{v}$ svete radiouglerodnogo datirovaniya [Chronological Correlation of the Eneolithic Cultures in the Volga-Urals Region in the Light of Radiocarbon Dating.]. $R A, 2010$, no. 4, pp. 19-28.

34. Mosin V.S., Epimakhov A.V., Vybornov A.A., Korolev A.I. Khronologiya eneolita i epokhi ranney bronzy v Uralskom regione [Chronology of the Eneolithic and the Early Bronze Age in the Ural Region]. Arkheologiya, etnografiya $i$ antropologiya Evrazii [Archaeology, Ethnography and Atnthropology of Eurasia], 2014, no. 4 (60), pp. 41-53.

35. Tsalkin V.I. Drevneyshie domashnie zhivotnye Vostochnoy Evropy [The Most Ancient Domestic Animals of Eastern Europe]. Moscow, Nauka Publ., 1970. 270 p. 36. Chernykh E.N., Orlovskaya L.B. Radiouglerodnaya khronologiya drevneyamnoy obshchnosti i istoki kurgannykh kultur [Radiocarbon Chronology of the Pit Grave Community and Origins of Barrow Cultures]. RA, 2004, no. 1, pp. 84-99.

37. Shilov V.P. Problemy osvoeniya stepey Nizhnego Povolzhya v epokhu bronzy [The Problems of Steppes Colonization in the Lower Volga Region in the Bronze Age]. Arkheologicheskie soobshcheniya Gosudarstvennogo Ermitazha [Archaeological Papers of the State Hermitage Museum]. Leningrad, 1964, no. 6, pp. 86-102.

38. Shishlina N.I. Severo-Zapadnyy Prikaspiy v epokhu bronzy (V-III tys. do n.e.) [North-West Caspian Sea Region in the Bronze Age ( $5^{\text {th }}-$ $3^{\text {rd }}$ Millennium BC)]. Moscow, GIM, 2007. 400 p.

39. Yudin A.I. Varfolomeevskaya stoyanka $i$ neolit stepnogo Povolzhya [Varfolomeevskaya Site and the Neolithic of the Steppe Volga Region]. Saratov, Nauchnaya kniga Publ., 2004. 199 p.

40. Grant A. The use of Tooth Wear as a Guide to the Age of Domestic Ungulates. Wilson B., Grigson C., Payne S., eds. Ageing and Sexing Animal Bones from Archaeological Sites. Oxford, BAR (British Series) 109, 1982, pp. 91-108.

\section{Information about the Authors}

Nina L. Morgunova, Doctor of Sciences (History), Professor, Chief Researcher, Archaeological Laboratory, Orenburg State Pedagogical University, Sovetskaya St., 19, 460014 Orenburg, Russian Federation, nina-morgunova@yandex.ru, https://orcid.org/0000-0002-8091-7411

Natalia V. Roslyakova, Candidate of Sciences (History), Senior Researcher, Archaeological Laboratory, Samara State University of Social Sciences and Education, M.Gorkogo St., 65/67, 443099 Samara, Russian Federation, roslyakova_n@mail.ru https://orcid.org/0000-0002-1888-2713 


\section{АРХЕОЛОГИЯ}

Marianna A. Kulkova, Candidate of Sciences (Geology and Mineralogy), Associate Professor, Department of Geology and Geoecology, Herzen State Pedagogical University, r. Moyki Emb., 48/12, 191186 Saint Petersburg, Russian Federation, kulkova@mail.ru, https://orcid.org/0000-0001-9946-8751

\section{Информация об авторах}

Нина Леонидовна Моргунова, доктор исторических наук, профессор, главный научный сотрудник археологической лаборатории, Оренбургский государственный педагогический университет, ул. Советская, 19, 460014 г. Оренбург, Российская Федерация, nina-morgunova@yandex.ru, https://orcid.org/0000-0002-8091-7411

Наталья Валерьевна Рослякова, кандидат исторических наук, старший научный сотрудник археологической лаборатории, Самарский государственный социально-педагогический университет, ул. М. Горького, 65/67, 443099 г. Самара, Российская Федерация, roslyakova_n@mail.ru, https://orcid.org/0000-0002-1888-2713

Марианна Алексеевна Кулькова, кандидат геолого-минералогических наук, доцент кафедры геологии и геоэкологии, Российский государственный педагогический университет им. А.И. Герцена, наб. р. Мойки, 48/12, 191186 г. Санкт-Петербург, Российская Федерация, kulkova@mail.ru, https://orcid.org/0000-0001-9946-8751 